\title{
PENGARUH VARIASI SUHU PENGERINGAN TERHADAP SIFAT FISIKO KIMIA TEH DAUN
} SAMBILOTO (Andrographis paniculata)

\author{
[Influence of Dried Temperature Variation to Chemical Physical Properties Tea Leaf (Andrographis \\ paniculata)]
}

\author{
Elsa Wiriani Patin*, Mohammad Abbas Zaini, Yeni Sulastri \\ Program Studi Ilmu dan Teknologi Pangan, Fakultas Teknologi Pangan dan Agroindustri, Universitas Mataram \\ *Email: elsawiriani275@gmail.com
}

Diterima 4 Januari 2018/ Disetujui 16 April 2018

\begin{abstract}
The aim of this research is to find out the influence of drying temperature variation on physico chemical characteristic of Andrographis paniculata leaf tea which include moisture content, ash content, antioxidant activity, extract level in water and organoleptic (color, flavor And aroma) on the leaves of sambiloto tea (Andrographis paniculata). This study was designed using Completely Randomized Design (RAL) with 5 level treatments and 4 replications. The result of the observation was analyzed by using analysis of variance at $5 \%$ significance level. The treatment consisted of one factor that influence the variation of drying temperature $50,55,60,65$ and $70^{\circ} \mathrm{C}$ with 50 minutes drying time. The results showed that the drying temperature of leaf bitter tea had significant effect moisture on content, ash content, antioxidant activity, water extract level, hedonic organoleptic parameters and scores (color, flavor and aroma). The results of this study indicate that drying with temperature $60^{\circ} \mathrm{C}$ produces leaf sambiloto tea with the best quality of moisture content (8.16\%), ash contant (8.04\%), antioxidant activity (78.29\%), water soluble extract (41,93\%) as well as organoleptic aroma (neutral and somewhat typical bitter leaf smell), taste (dislike and very bitter) and color (neutral and brownish yellow).
\end{abstract}

Keywords: drying, sambiloto, tea.

\section{ABSTRAK}

Penelitian ini bertujuan untuk mengetahui pengaruh variasi suhu pengeringan terhadap sifat fisiko kimia teh daun sambiloto (Andrographis paniculata) yang meliputi kadar air, kadar abu, aktivitas antioksidan, kadar ekstrak dalam air, dan organoleptik (warna, rasa dan aroma) pada teh daun sambiloto (Andrographis paniculata). Penelitian ini dirancang menggunakan Rancangan Acak Lengkap (RAL) dengan 5 taraf perlakuan dan 4 ulangan. Hasil pengamatan dianalisis menggunakan analisis keragaman (Analysis of Variance) pada taraf nyata $5 \%$. Perlakuan terdiri dari satu faktor yaitu variasi suhu pengeringan $50,55,60,65$ dan $70^{\circ} \mathrm{C}$ dengan lama pengeringan yaitu 60 menit. Hasil penelitian menunjukkan bahwa suhu pengeringan dalam pembuatan teh daun sambiloto memberikan pengaruh yang berbeda nyata terhadap kadar air, kadar abu, aktivitas antioksidan, kadar ekstrak dalam air, parameter organoleptik hedonik dan skoring (warna, rasa dan aroma). Hasil penelitian menunjukkan bahwa pengeringan dengan suhu $60^{\circ} \mathrm{C}$ menghasilkan teh daun sambiloto dengan mutu terbaik yaitu kadar air $(8,16 \%)$, kadar abu $(8,04 \%)$, aktivitas antioksidan $(78,29 \%)$, kadar ekstrak larut dalam air $(41,93 \%)$ serta organoleptik aroma (netral dan aroma daun sambiloto agak khas), rasa (tidak suka dan sangat pahit) dan warna (netral dan kuning kecoklatan).

Kata kunci: pengeringan, sambiloto, teh.

\section{PENDAHULUAN}

Teh adalah jenis minuman yang paling banyak digemari oleh masyarakat Indonesia maupun dunia karena rasanya yang segar dan nikmat. Selain sebagai minuman penyegar, teh juga telah diyakini memiliki manfaat bagi kesehatan tubuh, terhindar dari obesitas dan panjang umur (Hartoyo, 2003). Kandungan flavonoid dalam teh merupakan antioksidan yang bersifat antikarsinogenik, kariostatik serta hipokolesterolemik. Beberapa peneliti lain juga menyebutkan bahwa teh dapat bekerja sebagai hipoglikemik dan menghambat aterosklerosis. Teh merupakan bahan minuman penyegar yang sudah lama dikenal. Beberapa kandungan senyawa kimia dalam teh dapat memberi kesan warna, rasa, dan aroma yang memuaskan peminumnya. Jadilah teh minuman penyegar yang nikmat.

Menurut data Head of Researcher Brand Researcher Indonesia, konsumsi teh orang Amerika, Jepang dan Eropa mencapai hampir $2,5 \mathrm{~kg} / \mathrm{kapita} /$ tahun. Sementara itu, konsumsi teh orang Indonesia hanya mencapai 0,8 $\mathrm{kg} / \mathrm{kapita} /$ tahun (Machmud, 2006). Rendahnya konsumsi teh di Indonesia bukan disebabkan karena orang Indonesia kurang gemar 
mengkonsumsi teh. Akan tetapi lebih disebabkan oleh rendahnya angka produksi teh dalam negeri bila dibandingkan dengan jumlah penduduk Indonesia (Rohdiana, 2006 dalam Rijal, 2016).

Teh dapat dikelompokkan menjadi 2 golongan, yaitu teh herbal dan non herbal. Teh non herbal dikelompokkan lagi menjadi tiga golongan, yaitu teh hitam, teh hijau, dan teh oolong. Teh herbal adalah minuman yang mengandung herbal berkhasiat untuk kesehatan. Teh herbal terbuat dari bebungaan, bebijian, dedaunan atau akar dari beragam tanaman. Teh herbal dikonsumsi layaknya minuman teh, diseduh dan disajikan seperti biasa (Winarsi, 2011 dalam Rijal, 2016). Produk teh tidak hanya dihasilkan dari daun teh saja, namun dapat dihasilkan dari tanaman lain seperti daun sambiloto.

Sambiloto (Andrographis paniculata) merupakan salah satu jenis tanaman obat yang dapat tumbuh subur dan telah dibudidayakan di berbagai belahan dunia, termasuk di Indonesia, selain memiliki harga yang sangat terjangkau. Ditemukan bahan kimia andrographolide (beserta beberapa analognya), paniculide, farnesol, protein arabinogalactan, flavonoid, saponin, alkaloid, phenol, dan tannin dari ekstrak daun sambiloto. Beberapa penelitian telah membuktikan daun sambiloto memiliki efek antimikroba terhadap beberapa jenis bakteri (Cendranata, et al., 2011). Beberapa uji khasiat sambiloto terhadap penyakit seperti demam, infeksi lambung, infeksi pernafasan, demam malaria, repellent serangga, komplikasi diabetes, melindungi dari penyakitpenyakit hati, antiviral, immunostimulator dan menekan retenosis pada pasien angiosplastis (Rochmat, 2015). Tanaman sambiloto ini mudah di jumpai di Indonesia biasanya tumbuh di sekitar halaman rumah, kebun, lapangan rumput, sawah, ladang, semaksemak bahkan dipinggiran jalan.

Sambiloto adalah salah satu tanaman yang dapat digunakan sebagai obat anti diabetes mellitus. Herba dan percabangannya mengandung diterpen lakton yang terdiri dari andrografolid (zat pahit), neoandrografolid, 14-deoksi-11-12- didehidroandrografolid, 14deoksi-11 oksoandrografolid, 14 deoksi andrografolid, dan homoandrografolid selain itu juga terdapat juga flavonoid antara lain: 5hidroksi-2', 3', 7, 8-tetrametoksiflavon, hidroksi-2'7,8-trimetoksiflavon, 5-hidroksi7,2', 3'-trimetoksiflavon, 2',5-dihidroksi-7,8dimetoksiflavon, apigenin, onisilin, mono-0- metilwithin, 3,4-dicaffeoylquinic, dan apigenin7,4-dimetileter. Terdapat juga andrografin, panikulida A, B, dan C, dan panikulin (Niranjan et al., 2010; Sudarsono et al., 2006; Chao dan Lin, 2010 dalam Eka et al., 2011).

Menurut hasil penelitian Nainggolan (2012) dalam Rijal (2016) memanfaatkan daun kopi sebagai teh seduhan yang menghasilkan uji organoleptik terbaik dengan interaksi lama fermentasi 90 menit dan suhu pengeringan $95^{\circ} \mathrm{C}$. Menurut hasil penelitian Gista (2014), pengolahan teh daun sirsak dan kulit jeruk purut dengan lama pengeringan terbaik dan diterima oleh masyarakat yaitu lama pengeringan 30 menit dengan suhu $50^{\circ} \mathrm{C}$. Daun sirsak dan kulit jeruk purut mengandung tanin yang bersifat tahan terhadap panas, sehingga aktivitas antioksidan pada teh tersebut tidak rusak apabila dipanaskan. Proses pengolahan teh bunga lotus dilakukan pelayuan selama 8 jam dan 10 jam dan dilakukan pemaparan diatas jaringan lapis tipis serta diberikan aliran udara menggunakan kipas angin dan lama pelayuan 8 jam menghasilkan proses oksidasi enzimatis terbaik. Dalam proses pengolahan teh daun kelor pengeringan tidak dilakukan dengan sinar matahari namun dikeringkan dengan oven atau cabinet dryer pada suhu stabil antar $30-35^{\circ} \mathrm{C}$ selama 2 hari sampai benar-benar kering atau kadar air kurang dari 5\%, disimpan di tempat yang gelap atau kering. Kualitas teh dengan mempertahankan nilai nutrisinya sangat berpengaruh terhadap proses pengolahan yang dilakukan sehingga menghasilkan rasa, aroma yang berbeda-beda setiap teh (Rijal, 2016).

Beberapa informasi dan pengalaman beberapa praktisi Herbalis dalam memilih bahan baku daun sambiloto sebelum diolah menjadi ramuan herbal yang bermanfaat, disarankan untuk memilih daun sambiloto yang sudah tua. Penjemuran sambiloto dapat dilakukan dengan menggunakan sinar matahari, oven, fresh dryer maupun kombinasi matahari dengan alat/blower. Menurut Rusli et al. (2004) dalam Sembiring (2005), pengeringan kombinasi antara matahari dengan alat blower menghasilkan mutu simplisia yang lebih baik dibandingkan dengan jenis pengering matahari dan alat blower. Pada waktu pengeringan yang perlu diperhatikan adalah suhu dan kadar air bahan, karena pengeringan dengan menggunakan panas yang berlebihan dapat merusak mutu produk yang dihasilkan. Mutu yang dimaksud adalah warna, tekstur, flavor dan karakteristik 
mutu produk. Suhu pengeringan untuk tanaman sambiloto yaitu $50^{\circ} \mathrm{C}$ dan kadar air simplisianya maksimal 10\%. Berdasarkan uraian tersebut, dilakukan penelitian untuk mengetahui pengaruh variasi suhu pengeringan terhadap sifat fisikokimia teh daun sambiloto (Andrographis paniculata) untuk menghasilkan teh yang memiliki kualitas terbaik.

\section{METODOLOGI}

\section{Bahan dan Alat}

Bahan yang digunakan dalam penelitian ini adalah daun sambiloto dari Desa Padak Kecamatan Lembar Kabupaten Lombok Barat, air, methanol dan DPPH grade PA.

Alat-alat yang digunakan dalam penelitian ini adalah timbangan digital, Oven Dryer, labu ukur, pipet tetes, labu takar, baskom, gelas, pisau, tissue, Erlenmeyer, nampan, cawan porselin, timbangan analitik, botol timbang, spektrofotometer UV-Vis, gelas plastik, tanur, rak tabung reaksi, kertas label, sarung tangan, stopwatch dan desikator.

\section{Rancangan Percobaan}

Metode yang digunakan dalam penelitian ini adalah metode eksperimental yang dilaksanakan di laboratorium. Rancangan yang digunakan dalam penelitian ini adalah Rancangan Acak Lengkap (RAL) yang terdiri atas 5 aras dengan faktor tunggal yaitu pengaruh variasi suhu pengeringan. Perlakuannya yaitu suhu pengeringan $50^{\circ} \mathrm{C}$ $(\mathrm{P} 1)$, suhu pengeringan $55^{\circ} \mathrm{C}(\mathrm{P} 2)$, suhu pengeringan $60^{\circ} \mathrm{C}(\mathrm{P} 3)$, suhu pengeringan $65^{\circ} \mathrm{C}$ (P4) dan suhu pengeringan $70^{\circ} \mathrm{C}(\mathrm{P} 5)$.

Parameter yang diamati dalam penelitian ini adalah kualitas teh katuk meliputi sifat kimia, fisik dan organoleptik. Sifat kimia meliputi kadar air dan aktivitas antioksidan. Sifat fisik meliputi ekstrak larut dalam air dan sifat organoleptik meliputi rasa, aroma dan warna dengan menggunakan metode afektif dan deskriptif. Data hasil pengamatan dianalisis menggunakan analisis keragaman (Analysis of Variance) pada taraf nyata $5 \%$. Bila terdapat perbedaan nyata, maka diuji lanjut dengan uji Beda Nyata Jujur (BNJ) pada taraf yang sama.

\section{Tahapan Penelitian}

\section{Persiapan Bahan Baku}

Proses pemetikan sambiloto segar tanpa cacat dan berwarna hijau tua

\section{Disortasi}

Daun sambiloto segar disortasi dipisahkan dari batang dan tangkainya serta diseleksi daun yang kuning berbintik putih atau rusak dipisahkan dan dibuang.

\section{Pelayuan}

Pelayuan bertujuan untuk mengurangi kadar air didalam daun sambiloto segar agar proses pengeringan lebih cepat terjadi sehingga ketika dimasukkan ke oven tidak ada air yang turut terbawa, waktu pelayuan sekitar 24 jam dengan suhu $30^{\circ} \mathrm{C}$.

\section{Perajangan}

Daun sambiloto yang telah dilayukan kemudian dirajang kecil-kecil dengan tujuan untuk mempercepat pengeringan.

\section{Penimbangan}

Setelah dilakukan proses perajangan, daun sambiloto ditimbang dan digunakan sebanyak $100 \mathrm{~g}$ tiap perlakuan sehingga total semua perlakuan $2.000 \mathrm{~g}$.

\section{Pengeringan}

Pengeringan dilakukan menggunakan Oven Dryer dengan suhu pengeringan $50^{\circ} \mathrm{C}$, $55^{\circ} \mathrm{C}, 60^{\circ} \mathrm{C}, 65^{\circ} \mathrm{C}$ dan $70^{\circ} \mathrm{C}$ dengan lama pengeringan 60 menit.

\section{Penyeduhan}

Proses penyeduhan dilakukan dengan mengambil daun sambiloto kering sebanyak 3 $\mathrm{g}$ dan air panas dengan suhu $100^{\circ} \mathrm{C}$ sebanyak $200 \mathrm{ml}$, setelah itu dilakukan uji organoleptik dari segi rasa, aroma dan warna teh sambiloto.

\section{HASIL DAN PEMBAHASAN}

\section{Mutu Kimia}

Hasil pengamatan dan hasil analisis keragaman menunjukkan bahwa perlakuan variasi suhu pengeringan memberikan pengaruh yang berbeda nyata terhadap parameter kadar air, kadar abu dan aktivitas antioksidan.

\section{Kadar Air}

Perlakuan variasi suhu memberikan pengaruh yang berbeda nyata terhadap kadar air teh sambiloto. Pengaruh variasi suhu pengeringan terhadap kadar air teh sambiloto dapat dilihat pada Gambar 1.

Berdasarkan Gambar 1 menunjukkan bahwa perlakuan variasi suhu pengeringan berbeda nyata terhadap kadar air teh sambiloto. Kadar air tertinggi diperoleh pada perlakuan suhu pengeringan $50^{\circ} \mathrm{C}$ yaitu $10,70 \%$. Nilai kadar air terendah diperoleh pada perlakuan suhu pengeringan $70^{\circ} \mathrm{C}$ yaitu $5,27 \%$. Berdasarkan nilai rata-rata perlakuan variasi suhu pengeringan, semakin tinggi suhu 
pengeringan maka semakin rendah kadar air yang dihasilkan. Hal ini sesuai dengan hasil penelitian Yuliani (2013), bahwa semakin tinggi suhu selama pemanasan yang digunakan maka kandungan kadar air yang ada dalam bahan akan semakin menurun, sedangkan semakin rendah suhu dan lama pemanasan yang digunakan maka kandungan kadar air yang ada pada bahan hanya akan mengalami pengurangan yang tidak terlalu tinggi. Makin tinggi suhu udara pengering, makin besar energi panas yang dibawa udara sehingga makin banyak jumlah masa cairan yang diuapkan dari permukaan bahan yang dikeringkan (Winarti, 2011).

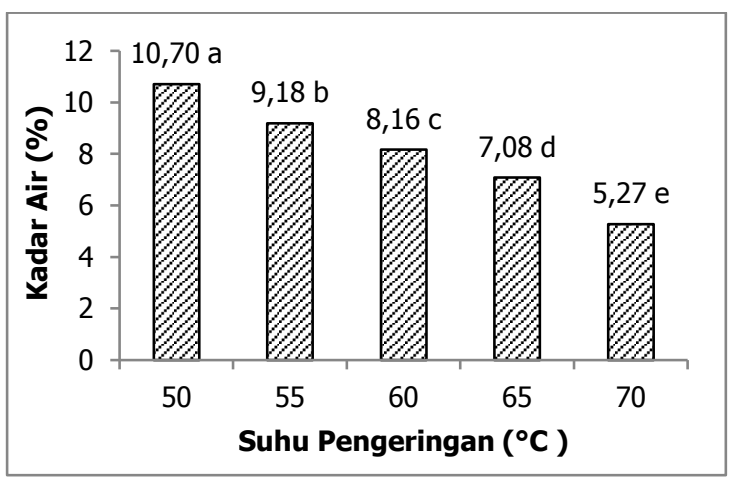

Gambar 1 Grafik Pengaruh Variasi Suhu Pengeringan Terhadap Kadar Air Teh Sambiloto

\section{Kadar Abu}

Perlakuan variasi suhu memberikan pengaruh yang berbeda nyata terhadap kadar abu teh sambiloto. Pengaruh variasi suhu pengeringan terhadap kadar abu teh sambiloto dapat dilihat pada Gambar 2. Berdasarkan Gambar 2 menunjukkan bahwa adanya pengaruh yang berbeda nyata terhadap kadar abu yang dihasilkan. Kadar abu tertinggi terdapat pada perlakuan suhu pengeringan $70^{\circ} \mathrm{C}$ yaitu $10,85 \%$. Nilai kadar abu terendah terdapat pada perlakuan suhu pengeringan $50^{\circ} \mathrm{C}$ yaitu $5,47 \%$. Hal tersebut diduga terjadi karena kandungan air bahan yang teruapkan lebih banyak sehingga mineral-mineral yang tertinggal pada bahan meningkat. Kadar abu menunjukkan residu bahan yang tersisa setelah bahan didestruksi dan menggambarkan banyaknya mineral yang tidak terbakar menjadi zat yang tidak dapat menguap.

Semakin tinggi suhu pengeringan, maka kadar abu semakin meningkat. Hal ini sesuai dengan pernyataan Sudarmadji et al., (1989), bahwa kadar abu tergantung pada jenis bahan, cara pengabuan, waktu dan suhu yang digunakan saat pengeringan.

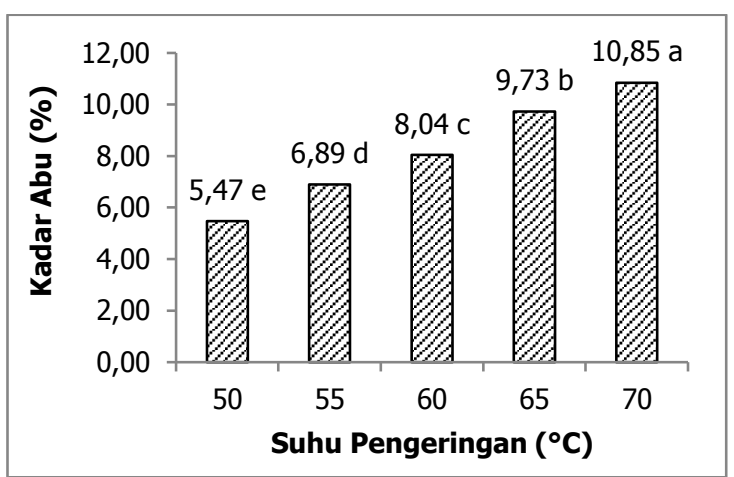

Gambar 2 Grafik Pengaruh Variasi Suhu Pengeringan Terhadap Kadar Abu Teh Sambiloto

\section{Aktivitas Antioksidan}

Perlakuan variasi suhu memberikan pengaruh yang berbeda nyata terhadap aktivitas antioksidan teh sambiloto. Pengaruh variasi suhu pengeringan terhadap aktivitas antioksidan teh sambiloto dapat dilihat pada Gambar 3.

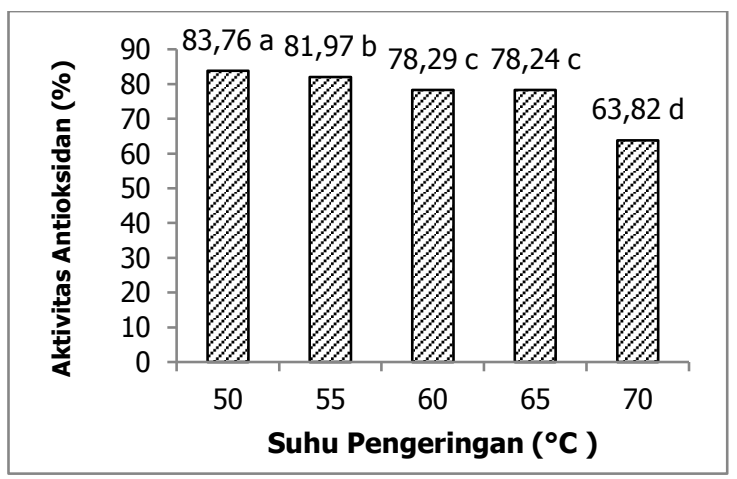

Gambar 3 Grafik Pengaruh Variasi Suhu Pengeringan Terhadap Aktivitas Antioksidan Teh Sambiloto

Berdasarkan Gambar 3 menunjukkan bahwa adanya pengaruh yang berbeda nyata terhadap aktivitas antioksidan teh sambiloto. Aktivitas antioksidan tertinggi terdapat pada perlakuan suhu pengeringan $50^{\circ} \mathrm{C}$ yaitu $83,76 \%$. Nilai terendah terdapat pada perlakuan suhu pengeringan $70^{\circ} \mathrm{C}$ yaitu $63,82 \%$. Semakin tinggi suhu pengeringan maka semakin rendah nilai aktivitas antioksidan yang dihasilkan. Semakin tinggi suhu pemanasan mengakibatkan senyawa metabolit sekunder yang bertindak sebagai antioksidan (senyawa flavonoid) rusak. Penelitian Hartanti dan Sri (2009) juga menunjukkan bahwa perbedaan perlakuan 
preparasi bahan baku berpengaruh terhadap aktivitas antioksidan. Pada bahan baku yang mengalami proses pengeringan, aktivitas antioksidan yang dihasilkan lebih kecil, hal ini disebabkan karena terjadinya degradasi atau kerusakan senyawa-senyawa rosella selama proses pengeringan. Beberapa senyawa antioksidan mengalami kerusakan sehingga aktivitas antioksidannya turun.

Senyawa antioksidan yang terdapat didalam daun sambiloto yaitu andrograpolid, flavonoid, tannin, saponin dan vitamin C. Menurut Lomlim et al. (2003), bahwa andrograpolid dalam bentuk kristal dan amor phous stabil pada suhu $70^{\circ} \mathrm{C}$ dan kelembaban $75 \%$ selama dua bulan. Menurut Lenny (2006) senyawa flavonoid bersifat tidak tahan panas dan mudah teroksidasi pada suhu yang tinggi. Flavonoid menunjukkan sensitivitas yang berbeda dalam perlakuan panas tergantung pada strukturnya (Irina dan Mohamed, 2012). Bagaimanapun strukturnya, flavonoid akan terdegradasi pada suhu diatas $100^{\circ} \mathrm{C}$. Flavonoid peka terhadap panas karena kelompok hidroksil dan ketonnya, serta ikatan ganda tak jenuh. Menurut Enny dan Fadilah (2007), kenaikan suhu hingga $55^{\circ} \mathrm{C}$ mengakibatkan kadar tannin yang didapat meningkat. Akan tetapi pada suhu di atas $55^{\circ} \mathrm{C}$ kadar tannin yang didapat menurun, sehingga dapat disimpulkan bahwa senyawa tannin akan mengalami kerusakan pada suhu diatas $55^{\circ} \mathrm{C}$. Menurut de Silva (1972) dalam Thoha (2009), senyawa saponin akan mengalami kerusakan pada suhu diatas 60$70^{\circ} \mathrm{C}$. Hayati et al. (2011) menyatakan bahwa, pengeringan kelopak rosella pada suhu $60^{\circ} \mathrm{C}$ selama 2×24 jam menyebabkan rendahnya kandungan vitamin $\mathrm{C}$ pada teh Rosella.

\section{Mutu Fisik}

Hasil pengamatan dan hasil analisis keragaman menunjukkan bahwa perlakuan variasi suhu pengeringan memberikan pengaruh yang berbeda nyata terhadap parameter ekstrak larut dalam air. Pengaruh variasi suhu pengeringan terhadap ekstrak larut dalam air teh sambiloto dapat dilihat pada Gambar 4.

Berdasarkan Gambar 4 menunjukkan bahwa perlakuan variasi suhu pengeringan berbeda nyata terhadap kadar ekstrak larut dalam air. Kadar ekstrak larut dalam air tertinggi terdapat pada perlakuan suhu pengeringan $70^{\circ} \mathrm{C}$ yaitu $43,89 \%$. Nilai kadar ekstrak larut dalam air terendah terdapat pada perlakuan suhu pengeringan $50^{\circ} \mathrm{C}$ yaitu $30,63 \%$. Berdasarkan nilai rata-rata perlakuan variasi suhu pengeringan, semakin tinggi suhu pengeringan maka semakin banyak kadar ekstrak larut dalam air yang dihasilkan. Hasil kadar ekstrak berbanding terbalik dengan kadar air. Hal ini diduga terjadi karena semakin tinggi suhu pengeringan daun sambiloto, pada berat bahan yang sama maka semakin rendah kadar air yang dihasilkan, sehingga dihasilkan ekstrak yang semakin banyak. Sejalan dengan penelitian Putri (2012) yang menyatakan bahwa semakin rendah kadar air maka semakin tinggi komponen lain yang tekandung dalam bahan yang berakibat kepada semakin tingginya persentase kadar ekstrak. Hal ini disebabkan oleh suhu operasi menjadi tinggi sehingga ada kemungkinan bahwa volatil menguap terbawa aliran gas panas.

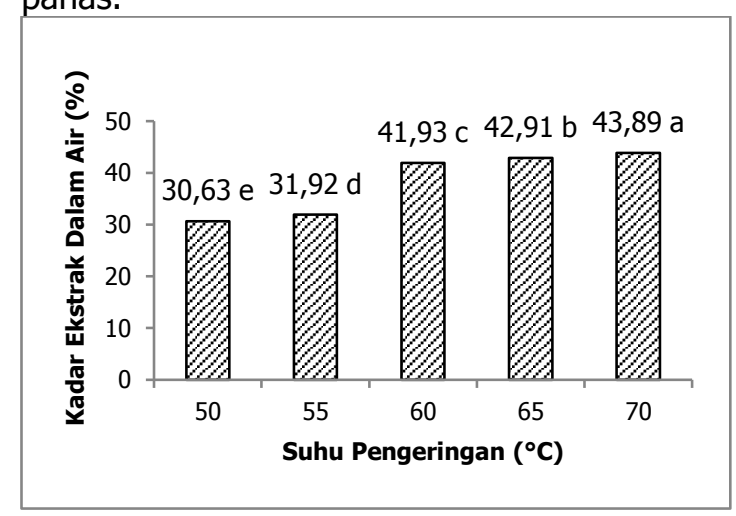

Gambar 4 Grafik Pengaruh Variasi Suhu Pengeringan Terhadap Ekstrak Larut Dalam Air Teh Sambiloto

Prinsip yang bekerja pada proses ekstraksi adalah difusi, yaitu perbedaan konsentrasi antara larutan didalam sel dan konsentrasi cairan ekstraksi diluar sel. Bahan pelarut mengalir dari luar (konsentrasi tinggi) ke dalam sel (konsentrasi rendah) yang menyebabkan protoplasma membengkak sehingga kandungan senyawa metabolit sekunder yang berada di dalam sel akan mengalir atau berdifusi keluar sel (Achmadi, 1992 dalam Agustiningrum 2004).

\section{Mutu Organoleptik}

\section{Aroma}

Perlakuan variasi suhu pengeringan memberikan pengaruh yang berbeda nyata pada uji organoleptik aroma teh sambiloto. Purata variasi suhu pengeringan terhadap aroma teh sambiloto dapat dilihat pada Gambar 5.

Berdasarkan Gambar 5 menunjukkan bahwa perlakuan variasi suhu pengeringan 
memberikan pengaruh yang berbeda nyata terhadap aroma teh sambiloto pada uji hedonik maupun skoring. Pada penilaian uji hedonik panelis memberikan nilai sangat tidak suka hingga suka terhadap aroma teh sambiloto dengan kisaran 2,7-6,5 dengan nilai tertinggi pada perlakuan suhu pengeringan $50^{\circ} \mathrm{C}$ dan nilai terendah terdapat pada perlakuan suhu pengeringan $70^{\circ} \mathrm{C}$. Semakin tinggi suhu pengeringan maka tingkat kesukaan panelis terhadap aroma teh sambiloto semakin menurun.

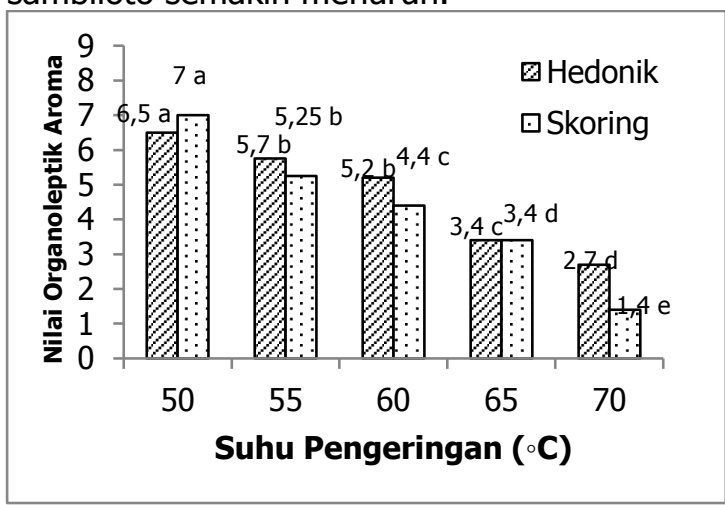

Gambar 5 Grafik Pengaruh Variasi Suhu Pengeringan Terhadap Organoleptik Aroma Teh Sambiloto

Penilaian uji skoring menunjukkan bahwa variasi suhu memberikan pengaruh yang berbeda nyata terhadap aroma teh sambiloto. Panelis memberikan nilai aroma sambiloto amat sangat khas hingga aroma daun sambiloto amat sangat tidak khas dengan kisaran nilai 1,4-7 dengan nilai tertinggi pada perlakuan suhu pengeringan $50^{\circ} \mathrm{C}$ dan nilai terendah terdapat pada perlakuan suhu pengeringan $70^{\circ} \mathrm{C}$. Panelis lebih menyukai aroma daun sambiloto yang amat sangat tidak khas. Hal ini disebabkan karena semakin tinggi suhu pengeringan aroma daun sambiloto menjadi amat sangat khas. Menurut ciptadi dan nasution (1979) menyatakan bahwa senyawa pembentuk aroma teh terutama terdiri dari minyak atsiri yang bersifat mudah menguap dan bersifat mudah direduksi sehingga dapat menghasilkan aroma harum pada teh.

\section{Rasa}

Perlakuan variasi suhu pengeringan memberikan pengaruh yang berbeda nyata pada uji organoleptik rasa teh sambiloto. Purata variasi suhu pengeringan terhadap rasa teh sambiloto dapat dilihat pada Gambar 6 .

Berdasarkan Gambar 6 menunjukkan bahwa perlakuan variasi suhu pengeringan memberikan pengaruh yang berbeda nyata terhadap aroma teh sambiloto pada uji hedonik maupun skoring. Pada penilaian uji hedonik panelis memberikan nilai sangat tidak suka hingga suka terhadap aroma teh sambiloto dengan kisaran 2,7-6,5 dengan nilai tertinggi pada perlakuan suhu pengeringan $50^{\circ} \mathrm{C}$ dan nilai terendah terdapat pada perlakuan suhu pengeringan $70^{\circ} \mathrm{C}$. Semakin tinggi suhu pengeringan maka tingkat kesukaan panelis terhadap aroma teh sambiloto semakin menurun.

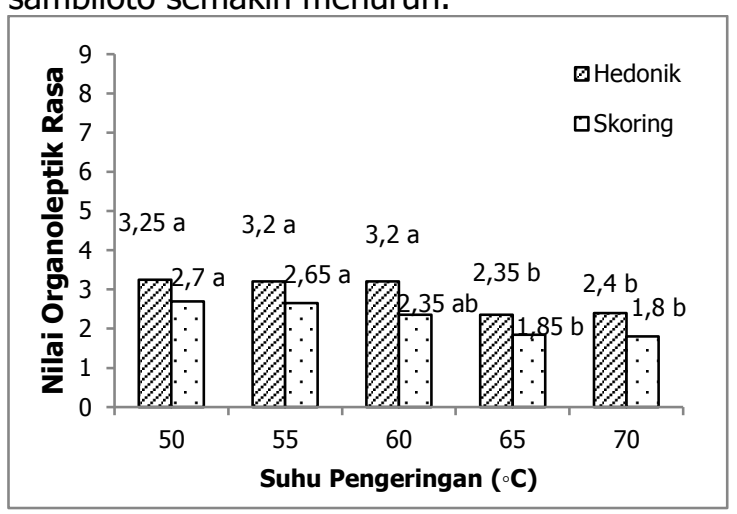

Gambar 6 Grafik Pengaruh Variasi Suhu Pengeringan Terhadap Organoleptik Rasa Teh Sambiloto

Penilaian uji skoring menunjukkan bahwa variasi suhu memberikan pengaruh yang berbeda nyata terhadap aroma teh sambiloto. Panelis memberikan nilai aroma sambiloto amat sangat khas hingga aroma daun sambiloto amat sangat tidak khas dengan kisaran nilai 1,4-7 dengan nilai tertinggi pada perlakuan suhu pengeringan $50^{\circ} \mathrm{C}$ dan nilai terendah terdapat pada perlakuan suhu pengeringan $70^{\circ} \mathrm{C}$. Panelis lebih menyukai aroma daun sambiloto yang amat sangat tidak khas. Hal ini disebabkan karena semakin tinggi suhu pengeringan aroma daun sambiloto menjadi amat sangat khas. Menurut Ciptadi dan Nasution (1979) menyatakan bahwa senyawa pembentuk aroma teh terutama terdiri dari minyak atsiri yang bersifat mudah menguap dan bersifat mudah direduksi sehingga dapat menghasilkan aroma harum pada teh.

\section{Warna}

Perlakuan variasi suhu pengeringan memberikan pengaruh yang berbeda nyata pada uji organoleptik warna teh sambiloto. Purata variasi suhu pengeringan terhadap warna teh sambiloto dapat dilihat pada Gambar 7.

Berdasarkan Gambar 7 menunjukkan bahwa perlakuan variasi suhu memberikan 
pengaruh yang berbeda nyata terhadap warna teh sambiloto pada uji hedonik maupun skoring. Pada penilaian uji hedonik panelis memberikan nilai agak tidak suka hingga agak suka terhadap warna teh sambiloto dengan kisaran nilai 4,2-6,05 dengan nilai tertinggi pada perlakuan dengan suhu pengeringan $55^{\circ} \mathrm{C}$, diikuti dengan suhu pengeringan $65^{\circ} \mathrm{C}$ dan dengan suhu pengeringan $50^{\circ} \mathrm{C}$ serta nilai terendah terdapat pada perlakuan dengan suhu pengeringan $70^{\circ} \mathrm{C}$.

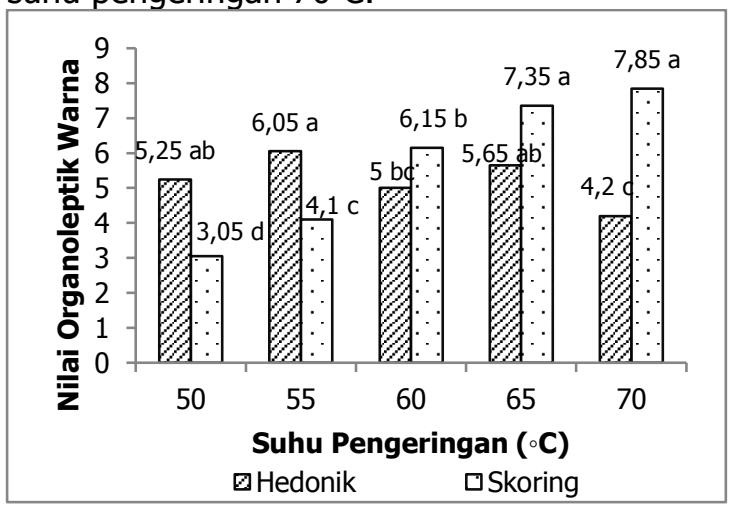

Gambar 7 Grafik Pengaruh Variasi Suhu Pengeringan Terhadap Organoleptik Warna Teh Sambiloto

Penilaian uji skoring menunjukkan bahwa variasi suhu memberikan pengaruh yang berbeda nyata terhadap warna teh sambiloto. Panelis memberikan nilai warna sambiloto hijau kekuningan hingga coklat dengan kisaran nilai 3,05-7,85 dengan nilai tertinggi terdapat pada perlakuan dengan suhu pengeringan $70^{\circ} \mathrm{C}$ dengan warna yang dihasilkan yaitu coklat dan nilai terendah terdapat pada perlakuan dengan suhu pengeringan $50^{\circ} \mathrm{C}$ dengan warna yang dihasilkan yaitu hijau kekuningan. Panelis lebih menyukai warna teh sambiloto yang berwarna kuning kehijauan. Hal ini disebabkan karena kecerahan warna seduhan teh dipengaruhi oleh senyawa turunan tanin yaitu theaflavin dan thearubigin. Theaflavin berperan dalam penentuan kecerahan warna seduhan teh. Semakin banyak kandungan theaflavin, maka kecerahan warna seduhan teh akan semakin tinggi, sedangkan thearubigin merupakan senyawa yang sulit larut dalam air dan berperan dalam menentukan kemantapan warna seduhan (warna teh menjadi merah cokelat). Warna teh yang cenderung merah cerah atau justru gelap disebabkan karena adanya theaflavin dan thearubigin (Rohdiana, 2006).

\section{KESIMPULAN}

Variasi suhu pengeringan memberikan pengaruh yang berbeda nyata terhadap kadar air, kadar abu, aktivitas antioksidan, kadar ekstrak dalam air dan organoleptik (Hedonik dan Skoring). Perlakuan terbaik teh sambiloto adalah perlakuan P3 dengan suhu pengeringan yaitu $60{ }^{\circ} \mathrm{C}$ dengan kadar air $(8,16 \%)$, kadar abu $(8,04 \%)$, aktivitas antioksidan $(78,29 \%)$, kadar ekstrak larut dalam air $(41,93 \%)$ serta aroma (netral dan aroma daun sambiloto agak khas), rasa (tidak suka dan sangat pahit) dan warna (netral dan kuning kecoklatan).

\section{DAFTAR PUSTAKA}

Cendranata WO, Mintarsih DK, dan Adiastuti EP. 2011. Daya hambat ekstrak daun sambiloto (Andrographis paniculata) terhadap populasi bakteri pada ulser recurrent aphthous stomatitis. J PDGI, 60(1): 20-23.

Eka SS, Agung EN, dan Suwijiyo P. 2011. Aktivitas antidiabetes kombinasi ekstrak terpurifikasi herba sambiloto (Andrographis paniculata (Burn.F.) NESS.) dan metformin pada tikus dm tipe 2 resisten insulin. Majalah Obat Tradisional,16(3): 124-132.

Enny KA dan Fadilah. 2007. Pengaruh kecepatan putar pengadukan dan suhu operasi pada ekstraksi tannin dari jambu mete dengan pelarut aseton. Ekuilibrium, 6 (1): 33-38.

Gista RA. 2014. Pemanfaatan Daun Sirsak (Annona muricata Lin) dan Kulit Jeruk Puruk (Cytrus hystrix) Sebagai Bahan Dasar Pembuatan Teh Dengan Variasi Lama Pengeringan. Skripsi. Fakultas Keguruan dan Ilmu Pendidikan Universitas Muhammadiyah. Surakarta.

Hartoyo A. 2003. Teh dan Khasiatnya bagi Kesehatan. Kanisius, Yogyakarta.

Lenny S. 2006. Bahan Ajar Metode Fitokimia. Laboratorium Kimia Organik Jurusan Kimia FMIPA Universitas Airlangga: Surabaya

Machmud I. 2006. Cerita Tentang Teh di Indonesia: Peluang Terbuka Luas. http:/www.rsi.sg/Indonesian/ruangbis nis/html. [Diakses pada tanggal 7 Januari 2017]. 
Rijal AS. 2016. Pengaruh Lama Pengeringan Terhadap Daya Oksidasi Teh Daun Kelor (Moringa oleifera) [Skripsi]. Mataram: Fakultas Teknologi Pangan dan Agroindustri, Universitas Mataram.

Rochmat A. 2015. Karakterisasi senyawa flavonoid ekstrak sambiloto (Andrographis paniculata) yang mempunyai aktivitas inhibisi terhadap enzim Siklooksigenase-2 secara in vitro. J Integrasi Proses, 5(2): 81.

Rohdiana D. 2006. Menyeduh Teh Dengan Baik, Benar Dan Menyehatkan. http://www.pikiranrakyat.com.cetak/20 06.122006/07/cakrawala/lainnya.02.ht $\underline{m}$. [Diakses pada tanggal 20 juli 2017].
Sembiring, Br, Bagem. 2005. Status Teknologi Pasca Panen Sambiloto (Andrographis paniculata Needs). Balai Penelitian Tanaman Obat dan Aromatik.

Sudarmadji S. 1989. Analisa Bahan Makanan dan Pertanian. Yogyakarta: liberty.

Winarti S, Sudaryanti dan Usman DS. 2011. Karakteristik dan Aktifitas Antioksidan Rosela Kering (Hibiscus sabdariffa L.). Seminar Nasional PATPI. Hal 15-17

Yuliani. 2013. Efek Suhu dan Lama Pemanasan Terhadap Sifat Fisika-Kimia Bubuk Pewarna dari Kelopak Bunga Rosela (Hibiscuss sabdariffa L.) yang Dihasilkan. Prosiding Seminar Nasional Kimia. Hal 121. 